\title{
Perbedaan Kadar Kalsium Darah pada Kehamilan Preeklamsia dengan Kehamilan Normotensi
}

\section{Differences in Blood Calcium Level between Preeclampsia and Normotensive Pregnancies}

\author{
Ika Murti Harini ${ }^{1}$, Tendi Novara ${ }^{2}$, Sutrisno ${ }^{3}$ \\ ${ }^{1}$ Bagian Histologi Fakultas Kedokteran Universitas Jenderal Soedirman Purwokerto \\ ${ }^{2}$ Bagian Anestesi dan Terapi Intensif Fakultas Kedokteran Universitas Jenderal Soedirman Purwokerto \\ ${ }^{3}$ Bagian Obstetri dan Ginekologi Fakultas Kedokteran Universitas Jenderal Soedirman Purwokerto
}

\begin{abstract}
ABSTRAK
Preeklamsia pada ibu hamil merupakan salah satu penyebab morbiditas dan mortalitas maternal dan perinatal baik di dunia maupun di Indonesia. Kadar kalsium darah yang rendah pada ibu hamil diduga berperan terhadap patogenesis preeklamsia. Penelitian ini bertujuan untuk mengetahui perbedaan kadar kalsium darah pada preeklamsia dengan kehamilan normotensi di RSUD Prof. Dr. Margono Soekarjo Purwokerto. Studi analitik observasional dengan pendekatan case control pada tiga kelompok penelitian yaitu preeklamsia ringan (PER), preeklamsia berat (PEB), dan kehamilan normotensi sebagai kelompok kontrol. Jumlah subjek tiap kelompok berjumlah 21 orang. Sampel darah diambil dari vena antecubiti dan disentrifuge untuk diambil serumnya. Pengukuran kadar kalsium dilakukan dengan metode Chresol Pthalein Complex. Hasil pada penelitian ini didapatkan rerata kadar kalsium darah pada kelompok PEB paling rendah $(8,34 \pm 0,32 \mathrm{mg} / \mathrm{dL})$ dan berbeda bermakna secara statitstik dibandingkan kelompok PER $(8,59 \pm 0,33 \mathrm{mg} / \mathrm{dL}) \mathrm{dan}$ normotensi $(8,71 \pm 0,31 \mathrm{md} / \mathrm{dL})$. Penelitian ini membuktikan potensi keterlibatan kalsium pada preeklamsia berat.
\end{abstract}

Kata Kunci: Kalsium darah, kehamilan, preeklamsia

\begin{abstract}
Preeclampsia in pregnant women is one of the causes of maternal and perinatal morbidities and mortalities both in the world and in Indonesia. Low blood calcium levels in pregnant women are thought to contribute to preeclampsia pathogenesis. This study aimed to determine the differences of blood calcium level in preeclampsia with normotensive pregnancy at RSUD Prof. Dr. Margono Soekarjo Purwokerto. This was an observational analytic study with case control approach which consisted of three groups, i.e. mild preeclampsia, severe preeclampsia, and normotensive pregnancy as the control group. The number of subjects per group was 21 people. Blood samples were taken from the antecubital vein and centrifuged for serum. Measurement of calcium level was done by Chresol Pthalein Complex method. The results of this study showed that the lowest average blood calcium level was in severe preeclampsia group (8.34 $\pm 0.32 \mathrm{mg} / \mathrm{dL}$ ) and statistically different significantly compared to those in mild preeclampsia group $(8.59 \pm 0.33 \mathrm{mg} / \mathrm{dL}$ ) and normotensive group $(8.71 \pm 0.31 \mathrm{mg} / \mathrm{dL}$ ). This study proves the potential of calcium involvement in severe preeclampsia.
\end{abstract}

Keywords: Blood calcium, preeclampsia, pregnancy

Korespondensi: Ika Murti H. Bagian Histologi Fakultas Kedokteran Universitas Jenderal Soedirman Purwokerto, Jl. Dr. Gumbreg No. 1 Purwokerto Tel. (0281)622022 Email:murti_cool@yahoo.com

DOI: http://dx.doi.org/10.21776/ub.jkb.2018.030.02.6 


\section{PENDAHULUAN}

Preeklamsia merupakan penyakit hipertensi dalam kehamilan yang ditandai dengan hipertensi (tekanan darah sistolik $\geq 140 \mathrm{mmHg}$ atau tekanan darah diastolik $\geq 90 \mathrm{mmHg}$ ) disertai proteinuria ( $\geq 300 \mathrm{mg} / \mathrm{dL}$ dalam urin tampung 24 jam) pada usia kehamilan lebih dari 20 minggu atau segera setelah persalinan (1). Preeklamsia merupakan salah satu penyebab utama morbiditas dan mortalitas maternal dan perinatal baik di dunia maupun di Indonesia disamping perdarahan dan infeksi atau sepsis (2). Insidensi preeklamsia di seluruh dunia berkisar antara 2-10\% dari kehamilan dan WHO memperkirakan insidensi preeklamsia tujuh kali lebih tinggi di negara berkembang dibandingkan di negara maju (3). Insiden preeklamsia di Indonesia sebesar 128.273 pertahun atau sekitar 5,3\% (4). Preeklamsia merupakan masalah kesehatan yang serius karena memberikan dampak pada bayi diantaranya prematuritas, berat badan lahir rendah, pertumbuhan janin terhambat yang berkontribusi pada besarnya angka morbiditas dan mortalitas perinatal (4).

Mekanisme atau patogenesis preeklamsia cukup kompleks. Saat ini, teori mekanisme preeklamsia dibedakan menjadi dua tahap. Tahap pertama bersifat asimptomatik, tanpa tanda dan gejala. Pada tahap pertama ini terjadi pembentukan plasenta abnormal dan pelepasan placental factor di sirkulasi maternal. Tahap kedua bersifat simptomatik, ditandai dengan hipertensi dan proteinuria. Pada kondisi berat dapat dijumpai angiospasme otak yang dapat menyebabkan kejang (5).

Faktor lain yang diduga berperan dalam terjadinya preeklamsia adalah kalsium. Kadar kalsium darah yang rendah berperan dalam perkembangan hipertensi dalam kehamilan maupun preeklamsia. Selama kehamilan, konsentrasi kalsium menurun secara progresif karena proses hemodilusi, sekresi urin yang meningkat, transfer mineral kalsium dari ibu ke janin yang meningkat serta intake rendah kalsium pada ibu hamil (6). Peran kalsium dalam preeklamsia masih kontroversi. Beberapa penelitian melaporkan kadar kalsium darah yang lebih rendah pada preeklamsia dibandingkan kelompok kontrol atau normotensi $(6,7,8,9)$. Sementara itu ada penelitian lain yang melaporkan bahwa tidak ada perbedaan kadar kalsium antara kelompok preeklamsia dengan kehamilan normotensi (10).

Rumah Sakit Umum Daerah Prof. Dr. Margono Soekarjo Purwokerto merupakan rumah sakit rujukan di Provinsi Jawa Tengah bagian selatan dan barat, yang banyak menerima pasien preeklamsia dengan tingkat keparahan dan komplikasi ringan hingga berat. Penelitian ini bertujuan untuk mengetahui peran kalsium dalam preeklamsia dengan melihat perbedaan kadar kalsium darah pada preeklamsia dengan kehamilan normotensi pada Rumah Sakit Umum Daerah Prof. Dr. Margono Soekarjo Purwokertos sebagai tempat studi. Hasil penelitian diharapkan dapat memperkuat peran keterlibatan kalsium dalam patogenesis preeklamsia.

\section{METODE}

Penelitian ini telah melalui telaah etik oleh Komisi Etik Penelitian Kesehatan Fakultas Kedokteran Universitas Jenderal Soedirman dengan Nomor: 1448/UN.23.07.5.1/PN.1/2017. Desain analitik observasional dengan menggunakan pendekatan case control dilakukan untuk mengetahui perbedaan kadar kalsium darah pada kehamilan dengan preeklamsia ringan, preeklamsia berat, dan kehamilan normotensi di RSUD Prof. Dr. Margono Soekarjo.

Teknik pengambilan sampel menggunakan metode nonprobability sampling. Sampel dipilih menggunakan consecutive sampling, yaitu setiap pasien yang datang berurutan dan memenuhi kriteria sampel akan dipilih hingga kuota penelitian terpenuhi. Pada penelitian ini diteliti kadar kalsium pada 3 kelompok, yaitu kelompok preeklamsia ringan, kelompok preeklamsia berat, dan kelompok kehamilan normotensi sebagai kelompok kontrol dengan usia kehamilan $\geq 20$ minggu di RSUD Prof. Dr. Margono Soekarjo selama periode penelitian dengan jumlah sampel yang sama masing-masing kelompok. Berdasarkan penghitungan sampel untuk studi case control (11) besar sampel untuk tiap kelompok sebesar 19. Untuk mengantisipasi kemungkinan drop out maka jumlah sampel ditambah sebesar $10 \%$ menjadi 21 orang untuk tiap kelompok.

Diagnosis preeklamsia ditentukan oleh dokter Sp.OG dengan kriteria sebagai berikut: (a) Preeklamsia ringan bila tekanan darah sistolik $\geq 140 \mathrm{mmHg}$ atau tekanan diastolik $\geq 90 \mathrm{mmHg}$ yang disertai ekskresi protein dalam urin dengan kadar $300 \mathrm{mg} / \mathrm{dL}$ dalam urin tampung 24 jam atau dengan pemeriksaan kualiatif $\geq 1+$ pada pengambilan sampel urin secara acak; (b) Preeklamsia berat, bila tekanan darah sistolik $\geq 160 \mathrm{mmHg}$ atau tekanan darah diastolik $\geq 110 \mathrm{mmHg}$ dengan ekskresi protein dalam urin dengan kadar $300 \mathrm{mg} / \mathrm{dL}$ dalam urin tampung 24 jam atau dengan pemeriksaan kualiatif $\geq 1+$ pada pengambilan sampel urin secara acak disertai salah satu kriteria berikut : (1) trombosit $<100.000$ per $\mathrm{mm}^{3}$, (2) peningkatan enzim hepar $\geq 2 x$ dari normal, (3) insufisiensi renal (kreatinin serum $>1,1 \mathrm{mg} / \mathrm{dl}$ ) atau oligouria (output urin $<500 \mathrm{ml}$ dalam 24 jam), (4) edema pulmoner atau sianosis, (5) gangguan serebral atau penglihatan onset baru, (6) nyeri berat persisten pada kuadran kanan atas atau regio epigastrik. Subjek pada kelompok kontrol atau kehamilan normotensi ditetapkan dengan kriteria kondisi kehamilan dengan tekanan sistole 100-140 $\mathrm{mmHg}$ dan tekanan diastole $60-90 \mathrm{~mm} \mathrm{Hg}$ tanpa proteinuria. Sampel darah dari responden diambil melalui vena antecubiti sebanyak $3 c c$. Darah disentrifuse, diambil serumnya dan selanjutnya diukur kadar kalsium dengan metode Chresol Pthalein Complex (CPC) di Laboratorium Patologi Klinik RSUD Prof. Dr. Margono Soekarjo Purwokerto. Prinsip pemeriksaan ini adalah ion kalsium bereaksi dengan o-cresolphthalein complexone dalam suasana basa untuk membentuk kompleks berwarna ungu. Absorbansi kompleks warna ini sebanding dengan konsentrasi kalsium dalam sampel.

Data usia ibu, usia kehamilan, dan kadar kalsium dianalisis menggunakan uji parametrik Anova karena jenis datanya numerik serta sebaran data normal dan homogen. Selanjutnya dilakukan uji post hoc LSD untuk mengetahui perbedaan kadar kalsium antar kelompok penelitian. Hasil analisis dianggap bermakna bila $p<0,05$. Perbedaan status paritas dianalisis menggunakan uji chi square karena jenis datanya kategorik nominal (12).

\section{HASIL}

Hasil penelitian menunjukkan bahwa rerata usia ibu yang mengalami preeklamsia berat (PEB) paling tinggi dibandingkan dengan kelompok kontrol (normotensi/NT) dan kelompok preeklamsia ringan (PER) meskipun secara 
statistik tidak bermakna $(p=0.545)$. Pada kelompok PEB diketahui rerata usia kehamilan ibu masih belum aterm yaitu 34,86 $\pm 3,76$ minggu lebih rendah dari kelompok kehamilan normal dan PER meskipun tidak bermakna secara statistik $(p=0.277)$. Pada penelitian ini, status paritas yang paling banyak pada semua kelompok adalah multipara. Berdasarkan analisis statistik, diketahui bahwa tidak ada perbedaan status paritas antarkelompok penelitian $(p=0,599)$ (Tabel 1$)$. Kedua kelompok dapat dikatakan homogen dari aspek usia ibu, usia kehamilan dan status paritas.

Tabel 1. Karakteristik subjek penelitian

\begin{tabular}{lrrrr}
\hline Variabel & $\begin{array}{c}\text { Kontrol atau } \\
\text { NT }(n=21)\end{array}$ & PER $(n=21)$ & PEB $(n=21)$ & p-value \\
\hline Usia ibu (tahun) & $29,76 \pm 6,30$ & $31,28 \pm 6,81$ & $32,09 \pm 7,63$ & $0,545^{\mathrm{a}}$ \\
Usia kehamilan (minggu) & $37,05 \pm 3,37$ & $36,09 \pm 5,69$ & $34,86 \pm 3,76$ & $0,277^{\mathrm{a}}$ \\
Status paritas (individu) & & & 7 & $0,599^{\mathrm{b}}$ \\
Nullipara & 8 & 5 & 7 & \\
Primi/multipara & 13 & 16 & 14 & \\
\hline
\end{tabular}

\section{Keterangan :}

- $p$-value) a tidak ada perbedaan signifikan dengan uji Anova

- $p$-value)b tidak ada perbedaan signifikan dengan uji Chi-Square

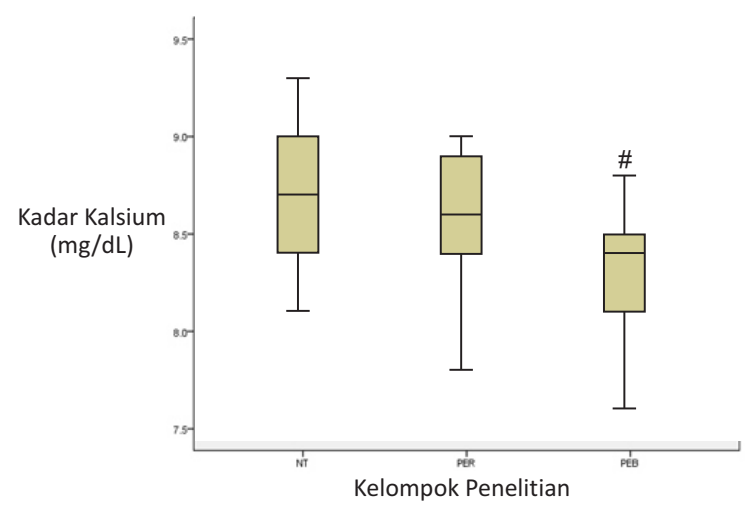

Gambar 1. Rerata kadar kalsium pada kelompok penelitian Keterangan: \# Rerata kadar kalsium pada kelompok preeklamsia berat (PEB) berbeda bermakna ( $p<0,05$, ANOVA) bila dibandingkan dengan kelompok kontrol (normotensi/NT) dan kelompok preeklamsia ringan (PER)

Hasil uji ANOVA didapatkan perbedaan bermakna $(p=0,002)$ antar kelompok dengan rerata kadar kalsium darah pada kelompok PEB paling rendah $(8,34 \pm 0,32 \mathrm{mg} / \mathrm{dL})$ dibandingkan kelompok PER $(8,59 \pm 0,33 \mathrm{mg} / \mathrm{dL})$ dan normotensi $(8,71 \pm 0,31 \mathrm{md} / \mathrm{dL})$. Uji postHoc menunjukkan kelompok PEB berbeda bermakna $(p<0,05)$ dibandingkan dengan kelompok normotensi dan PER (Gambar 1).

\section{DIKSUSI}

Meskipun tidak terdapat perbedaan bermakna secara statistik, hasil penelitian mendapatkan gambaran usia ibu pada $\mathrm{PEB}$ paling tinggi, dengan usia kehamilan paling rendah, dan sebagian besar multipara. Rerata usia ibu yang mengalami preeklamsia berat adalah $32,09 \pm 7,63$ tahun, paling tinggi dibandingkan dengan kelompok normotensi dan PER. Meskipun reratanya paling tinggi, namun usia ini masih termasuk dalam rentang usia reproduksi normal. Beberapa penelitian menyebutkan bahwa usia ibu di atas 35 tahun mempunyai peluang lebih tinggi untuk terjadinya preeklamsia dibandingkan usia ibu di bawah 35 tahun $(13,14)$. Sementara itu, penelitian lain melaporkan bahwa semakin tinggi usia ibu (>40 tahun) semakin berisiko mengalami preeklamsia dan risiko lain baik risiko yang terjadi pada antenatal, risiko saat persalinan maupun komplikasi yang terjadi pada janin (15).

Pada kelompok preeklamsia berat, usia kehamilan ibu lebih rendah dibandingkan kelompok normotensi dan PER. $\mathrm{Hal}$ ini sesuai dengan penelitian yang melaporkan bahwa usia kehamilan ibu yang mengalami preeklamsia lebih rendah dibandingkan usia kehamilan ibu pada kelompok kontrol (16). Penelitian tersebut juga melaporkan bahwa faktor yang mempengaruhi terjadinya preeklamsia selain usia kehamilan ibu adalah riwayat preeklamsia sebelumnya pada ibu (16). Penelitian lain melaporkan bahwa rerata usia kehamilan ibu yang mengalami preeklamsia adalah 39 $\pm 2,4$ minggu (17) dan dilaporkan juga jika usia kehamilan ibu sudah aterm (>37 minggu) maka berat bayi yang dilahirkan tidak berbeda dengan berat bayi yang dilahirkan dari ibu dengan kehamilan normotensi.

Pada penelitian ini sebagian besar ibu yang mengalami preeklamsia merupakan ibu yang sudah pernah melahirkan sebelumnya baik primi atau multipara. Hal ini sesuai dengan penelitian yang melaporkan bahwa ibu yang sudah pernah melahirkan mempunyai peluang lebih besar untuk terjadinya preeklamsia (15). Sementara laporan lain menyatakan bahwa nullipara atau ibu yang baru pernah hamil dan belum pernah melahirkan sebelumnya mempunyai peluang yang lebih tinggi untuk terjadinya preeklamsia (18). Penyebab adanya perbedaan dalam penelitian yang dilakukan dengan penelitian sebelumnya kemungkinan karena ada faktor risiko lain yang tidak diteliti dalam penelitian ini. Faktor risiko lain yang berperan dalam preeklamsia antara lain adanya penyakit pada ibu seperti penyakit ginjal, sindrom antibodi antifosfolipid, systemic lupus erythematosus, hipertensi kronis dan diabetes melitus. Faktor lain seperti obesitas, kehamilan ganda dan riwayat preeklamsia sebelumnya juga berperan dalam preeklamsia (18). Faktor-faktor tersebut tidak diteliti pada penelitian ini.

Penelitian ini mengidentifikasi perbedaan bermakna kadar kalsium dengan kadar terendah pada PEB. Kelompok normotensi mempunyai rerata kadar kalsium darah paling tinggi namun tidak berbeda bermakna dengan kelompok PER. Kadar kalsium pada kelompok normotensi ini termasuk dalam rentang normal karena diketahui kadar kalsium normal pada wanita dewasa adalah $8,5-10 \mathrm{mg} / \mathrm{dL}$. Rerata kadar kalsium darah paling rendah dijumpai pada kelompok PEB yaitu $8,34 \pm 0,32 \mathrm{mg} / \mathrm{dL}$. Hasil juga menggambarkan semakin berat derajat preeklamsia, semakin rendah kadar kalsium darahnya. Hal ini sesuai dengan penelitian yang juga melaporkan kadar kalsium darah kelompok PEB paling rendah dibandingkan kelompok normotensi dan PER (6). Begitu juga penelitian lain yang melaporkan adanya kadar kalsium yang rendah pada ibu hamil dengan preeklamsia dibandingkan ibu hamil yang tidak preeklamsia $(7,21,22)$.

Preeklamsia mempunyai patogenesis yang kompleks. Sebuah penelitian melaporkan adanya keterlibatan Human Leukocyte Antigen-C (HLA-C) dan Natural Killer cell (sel NK) dalam proses terjadinya preeklamsia (19). Penelitian lain melaporkan peran sitokin inflamasi khususnya Tumor 
Necrosis Factor- $\alpha$ (TNF- $\alpha$ ) dalam menimbulkan gejala preeklamsia (20). Banyak penelitian yang melaporkan keterlibatan mineral seperti kalsium dalam patogenesis preeklamsia. Kalsium sangat diperlukan untuk perkembangan normal dan menjaga fungsi tubuh. Kalsium diperlukan untuk berbagai macam proses penting seperti eksitabilitas neuron, pelepasan neurotransmitter, kontraksi otot, integritas membran dan pembekuan darah (6). Kalsium juga berperan penting selama proses kehamilan.

Peranan kalsium yang rendah pada ibu hamil dalam menyebabkan preeklamsia dapat dijelaskan melalui beberapa mekanisme, di antaranya bila kadar kalsium rendah maka akan meningkatkan pengeluaran hormon paratiroid dan selanjutnya menyebabkan peningkatan kalsium intraseluler pada otot polos vaskuler. Peningkatan kalsium intraseluler pada otot polos vaskuler ini akan menyebabkan peningkatan resistensi vaskuler dan vasokonstriksi yang akan memicu peningkatan tekanan darah $(6,23)$. Mekanisme lain dengan cara merangsang pengeluaran renin yang akan meningkatkan angiotensin II dan akan meningkatkan tekanan darah. Kadar kalsium yang rendah ini juga dapat menurunkan kadar magnesium darah dan selanjutnya memicu vasokonstriksi otot polos vaskular serta akan menurunkan efek endothelial nitric oxide synthase (eNOS), suatu enzim yang tergantung kalsium sehingga menghambat vasodilatasi pembuluh darah. Hambatan vasodilatasi ini juga disebabkan karena penurunan prostasiklin di sirkulasi. Prostasiklin merupakan enzim yang tergantung kalsium dan vasodilator yang poten (24).

Rendahnya kadar kalsium pada ibu hamil dapat disebabkan oleh proses hemodilusi, sekresi urin yang meningkat, transfer mineral kalsium dari ibu ke janin yang meningkat serta intake rendah kalsium pada ibu hamil (6).

\section{DAFTAR PUSTAKA}

1. Jeyabalan A. Epidemiology of Preeclampsia: Impact of Obesity. Nutrition Reviews. 2013; 71(1): 18-25.

2. Say L, Chou D, Gemmill A, et al. Global Causes of Maternal Death: A WHO Systematic Analysis. The Lancet Global Health. 2014; 2(6): e323-333.

3. Osungbade KO and Ige OK. Public Health Perspectives of Preeclampsia in Developing Countries: Implication for Health System Strengthening. Journal of Pregnancy. 2011; 2011: 1-6.

4. Wibowo N, Rima I, Edwina F, et al. Pedoman Nasional Pelayanan Kedokteran Diagnosis dan Tata Laksana Preeklamsia. Jakarta: Perkumpulan Obstetri dan Ginekologi Indonesia (POGI); 2016; hal. 2.

5. Ahmed A, Rezai $H$, and Broadway-Stringer $S$. Evidence-Based Revised View of the Pathophysiology of Preeclampsia. Advances in Experimental Medicine and Biology. 2017; 956: 355374.

6. Jain S, Sharma P, Kulshreshtha S, Mohan G, and Singh S. The Role of Calcium, Magnesium and Zinc in PreEclampsia. Biological Trace Element Research. 2010; 133(2): 162-170.

7. Mohieldein AH, Dokem AA, Osman YHM, and Idris HMA. Serum Calcium Level as a Marker of
Metabolisme atau absorbsi kalsium pada ibu hamil akan meningkat terutama pada trimester kedua dan ketiga (25). Peningkatan absorbsi ini berhubungan dengan intake kalsium pada ibu. Keterbatasan pada penelitian ini antara lain tidak diteliti asupan kalsium pada ibu sehingga tidak diketahui apakah kadar kalsium yang rendah ini disebabkan oleh intake yang rendah atau sebab yang lain. Bila memang penyebabnya karena intake kalsium yang rendah maka diperlukan tambahan kalsium selama kehamilan dengan dosis 1,5-2,0g kalsium/hari (26). Tambahan kalsium ini direkomendasikan untuk mencegah preeklamsia terutama pada wanita yang mempunyai risiko preeklamsia sebelumnya $(19,26)$. Keterbatasan yang lain pada penelitian ini adalah tidak meneliti mineral lain yang berperan pada kejadian preeklamsia seperti magnesium dan zink serta tidak meneliti intake makanan yang dikonsumsi ibu hamil. Penelitian ini juga tidak meneliti faktor risiko lain yang berperan dalam preeklamsia seperti riwayat penyakit pada ibu, obesitas, kehamilan ganda dan riwayat preeklamsia sebelumnya.

Hasil penelitian ini yang menunjukkan kadar kalsium darah pada PEB secara bermakna paling rendah dibandingkan PER dan kehamilan normotensi mendukung bukti potensi keterlibatan kalsium pada patogenesis preeklamsia. Studi lanjut perlu dilakukan dengan melihat asupan kalsium selama kehamilan untuk mengkaji faktor penyebab rendahnya kadar kalsium dalam kehamilan.

\section{UCAPAN TERIMAKASIH}

Peneliti mengucapkan terimakasih kepada Lembaga Penelitian dan Pengabdian Masyarakat Universitas Jenderal Soedirman (LPPM Unsoed) yang telah mendanai penelitian ini.

Pregnancy-Induced Hypertension. Sudan Journal of Medical Sciences. 2007; 2(4): 245-248.

8. Kumru S, Aydin S, Simsek M, Sahin K, Yaman M, and Ay G. Comparison of Serum Copper, Zinc, Calcium, and Magnesium Levels in Preeclamptic and Healthy Pregnant Women. Biological Trace Element Research. 2003; 949(2): 105-112.

9. Kanagal DV, Rajesh A, Rao K, et al. Levels of Serum Calcium and Magnesium in Pre-eclamptic and Normal Pregnancy: A Study from Coastal India. Journal of Clinical \& Diagnostic Research. 2014; 8(7): OC01-OC04.

10. Iou SG, Amirabi A, Yazdian M, and Pashapour N. Evaluation of Serum Calcium, Magnesium, Copper, and Zinc Levels in Women with Pre-eclampsia. Iranian Journal of Medical Science. 2008; 33(4): 231234.

11. Sastroasmoro S dan Ismael S. Dasar-dasar Metode Penelitian Klinis. Jakarta: Sagung Seto; 2011; hal. 359.

12. Dahlan MS. Statistik untuk Kedokteran dan Kesehatan. Jakarta: Penerbit Salemba Medika; 2013; hal. 90-101.

13. Lamminpää $R$, Vehviläinen-Julkunen K, Gissler $M$, and Heinonen S. Preeclampsia Complicated by Advanced Maternal Age: A Registry-Based Study on 
Primiparous Women in Finland 1997-2008. BioMed Central Pregnancy and Childbirth. 2012; 12: 47-51.

14. Kumari N, Dash K, and Singh R. Relationship between Maternal Age and Preeclampsia. Journal of Dental and Medical Sciences. 2016; 15(12): 55-57.

15. Jolly M, Sebire N, Harris J, Robinson S, and Regan L. The Risks Associated with Pregnancy in Women Aged 35 Years or Older. Human Reproduction. 2000; 15(11): 2433-2437.

16. Kashanian M, Baradaran HR, Bahasadri S, and Alimohammadi R. Risk Factors for Pre-Eclampsia: A Study in Tehran, Iran. Archives of Iranian Medicine. 2011; 14 (6): 412-415.

17. Xiong X, Demianczuk NN, Saunders LD, Wang FL, and Fraser WD. Impact of Preeclampsia and Gestational Hypertension on Birth Weight by Gestational Age. American Journal of Epidemiology. 2002; 155(3): 203-209.

18. Uzan J, Carbonnel M, Piconne O, Asmar R, and Ayoubi JM. Pre-eclampsia: Pathophysiology, Diagnosis, and Management. Vascular Health and Risk Management. 2011; 7: 467-474.

19. Sulistyowati S, Soetrisno, dan Nizar HK. Ekspresi Human Leukocyte Antigen-C di Trofoblas dan Natural Killer Cell di Desidua pada Preeklampsia Berat. Jurnal Kedokteran Brawijaya. 2016; 29(1): 59-63.

20. Agmar SY, Batiyani SCW, dan Fitri LE. Injeksi Serum Mengandung TNF- $\alpha$ Tinggi Menurunkan Konsentrasi VEGF dan Ekspresi Nephrin Glomerulus
Mencit Bunting. Jurnal Kedokteran Brawijaya. 2016; 29(1): 10-13.

21. Hofmeyr GJ, Roodt A, Atallah AN, and Duley L. Calcium Supplementation to Prevent Pre-eclampsiaA Systematic Review. South African Medical Journal. 2003; 93(3): 224-228.

22. Saurabh K, Ghalaut V, and Bala J. Study of Serum Calcium in Maternal and Cord Blood of Women with Preeclampsia and Normotensive Pregnancies. Scholars Academic Journal of Biosciences. 2015; 3(12): 1033-1039.

23. Chhabra $S$ and Singh A. Role of Calcium in Hypertensive Disorders of Pregnancy Current Status of Research a Mini Review. Journal of Nutritional Disorders and Therapy. 2017; 7(2): 1-5.

24. Richards DGD, Lindow SW, Carrara H, Knight R, Haswell SJ, and Van der Spuy ZM. A Comparison of Maternal Calcium and Magnesium Levels in Preeclamptic and Normotensive Pregnancies: An Observational Case-control Study. BJOG-An International Journal of Obstetrics and Gynaecology. 2014; 121(3): 327-336.

25. Hacker AN, Fung EB, and King JC. Role of Calcium during Pregnancy: Maternal and Fetal Needs. Nutrition Reviews. 2012; 70(7): 397-409.

26. World Health Organization. WHO Recommendations for Prevention and Treatment of Pre-eclampsia and Eclampsia. Geneva: World Health Organization; 2011: p.11. 